\title{
Efficiency of Ketapang (Terminalia catappa L.) Leaves Tannin Extract as Organic Inhibitor Against Corrosion Rate of Iron Metal in Seawater
}

\author{
Eddy Marlianto $^{1^{*}}$ and Rizki Ramadhani ${ }^{2}$ \\ ${ }^{1,2}$ Department of Physics, Faculty of Mathematics and Natural Science, Universitas Sumatera Utara \\ 20155, Indonesia
}

\begin{abstract}
The research is about effect of immersion time and mechanical properties on the rate of corrosion of ferrous metals by the addition of Ketapang (Terminalia catappa L.) leaf extract as an organic inhibitor in the seawater environment. In this study, ketapang leaf extract was used as a natural inhibitor to inhibit the rate of corrosion of ferrous metals. This inhibitor is used on iron metal plates which are immersed in corrosive media, namely sea water with variations in the composition of the inhibitors used at $0 ; 10 \% \mathrm{~V} ; 20 \% \mathrm{~V}$, and $40 \% \mathrm{~V}$, with immersion time of 3 and 6 days. The characterizations tested included measurement of density, corrosion rate, inhibitor efficiency, and hardness testing using the Vickers method. From the measurement results, the density value decreases with the addition of the concentration of the inhibitor both on immersion 3 days and 6 days. The value of hardness increases with increasing composition of the inhibitor. The optimum hardness value is $165.03 \mathrm{~N} / \mathrm{m}^{2}$ with immersion time of 6 days at an inhibitor concentration of $40 \%$ and a minimum hardness value of $145.603 \mathrm{~N} / \mathrm{m}^{2}$ on immersion 6 days with no inhibitor. The smallest corrosion rate was obtained by samples with a composition of $40 \%$ inhibitor of 2.77 mpy with immersion time of 3 days and 1.33 mpy with immersion time of 6 days. And the efficiency value of Ketapang leaf extract inhibitors reached $47.01 \%$ in the composition of $40 \%$ in the seawater environment with immersion time of 6 days.
\end{abstract}

Keyword: ketapang leaves, organic inhibitor, iron metal, seawater, corrosion rate, weight loss.

Received 18 November 2019 | Revised [10 December 2019] | Accepted [14 February 2020]

\section{Introduction}

Iron is the most important metal from a technical and economic point of view and has been linked with human history for about 5000 years. Iron plays the biggest role for strong development in a country [1-3]. In the treatment, iron is a type of metal that is very susceptible to attack by corrosion events. Because this metal is easily oxidized in all places, it is necessary to carry out special treatment for this ferrous metal in maintaining its original strength and mechanical properties.

\footnotetext{
*Corresponding author at: Jl. Biolteknologi no.1 Medan, 20155, Indonesia

E-mail address: eddymarlianto@usu.ac.id
} 
Journal of Technomaterial Physics Vol. 2, No. 1, 2020 / 63-69

Corrosion is an event of damage to metals caused by environmental influences (temperature, humidity, etc.) [4]. Corrosion is an event that often occurs in almost all metals and steel used for everyday purposes, such as cars, bridges, machinery, pipes, ships, industrial equipment. Several ways that can be done to slow down the rate of corrosion include coating metal surfaces, cathodic protection, adding additives as corrosion inhibitors [5-7]. The use of corrosion inhibitors is an effective method to inhibit corrosion, because it is cheap and simple. Corrosion inhibitors are substances that are added in small amounts to a metal and reduce the rate of corrosion. In general, corrosion inhibitors are organic and inorganic compounds that contain lone pairs, such as nitrites, chromates, phosphates, urea, phenylalanine, and amines which are dangerous, not environmentally friendly, and expensive. So we need a corrosion inhibitor that is safe, inexpensive, biodegadable and environmentally friendly [8-10].

Ketapang leaves contain flavonoids, tannins, saponins and triterpenoids. While the bark contains only flavonoids and saponins, in the fruit only tannins and steroids [11-12]. Several studies on the use of ketapang leaf extract have been conducted. For example, as an inhibitor of corrosion of mild steel (mild steel) in the pipeline in $1 \mathrm{M} \mathrm{H}_{2} \mathrm{SO}_{4}$ media, ketapang leaf extract can inhibit corrosion by 171.77460 mmpy.

In this research, the effect of ketapang leaf extract inhibitor will be carried out on the corrosion rate of ferrous metal in seawater. The method used in this study is the weight reduction method. And the tests carried out are tests of chemical properties such as corrosion rates. Physical properties such as density and electric potential, and test morphology and mechanical properties such as hardness.

\section{Methods}

Ketapang leaves are selected which are still green and then cleaned with water, dried and aerated for \pm 2 days and the leaves are turned back and forth to prevent fermentation or the growth of fungi, then in the oven at $40^{\circ} \mathrm{C}$ for 24 hours to dry. Then, the samples were blended using a dry blender until it becomes a powder. Furthermore, the powder was weighed 378 grams and then put into Erlenmeyer added $1134 \mathrm{~mL}$ of $70 \%$ ethanol to Erlenmeyer for maceration for 3 days.

After the maceration process is complete, there is sedimentation in the glass tube, then the separation process between the filtrate and the fibers is carried out by filtering using filter paper. The results of the separation are then put into a rotary evaporator at $80^{\circ} \mathrm{C}$ for 2 hours at a speed of $200 \mathrm{rpm}$ with a pressure of 0.5 bar until the ethanol evaporates so that a thick extract is obtained. Ketapang leaf extract will then be tested for its composition in the PTKI Bio-Process Laboratory. 
Pure seawater is the main corrosion medium in this study, then the volume varies with the concentration of ketapang leaf extract inhibitor $0 \%, 10 \%, 20 \%, 40 \% \mathrm{~V}$ with a ratio of 10:0, 9:1, 8:2, 6:4. The iron metal plate used is ferrous metal with the ASTM A36 standard with 4\% carbon content with a thickness of $0.11 \mathrm{~cm}$ and cut to a size of $6 \times 5 \mathrm{~cm}$. Then the metal surface was washed and then scraped using $4000 \mathrm{CW}$ sand paper to remove impurities. Then it is cleaned again with detergent and dried in an oven at $300^{\circ} \mathrm{C}$ for about 30 minutes. Then the ferrous metal is weighed and the result is expressed as the initial mass.

Characterization consisted of physical properties (density), mechanical properties (hardness), chemical properties (corrosion rate) using the weight loss method, inhibitor efficiency, and hardness testing using the Vickers method.

\section{Result and Discussion}

\subsection{Physical Properties (Density) of ketapang leaf extract as inhibitor}

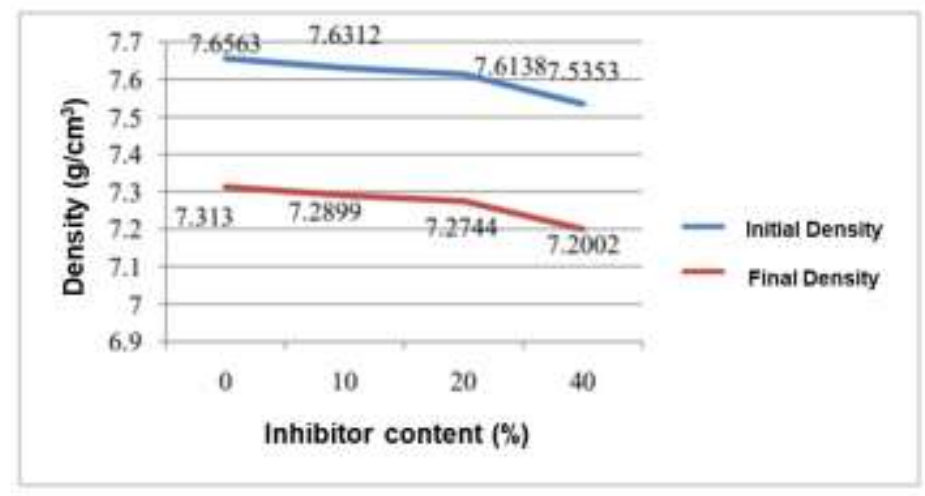

Figure 1. Graph of the relationship between iron metal density and ketapang leaf extract composition and immersion time for 3 days

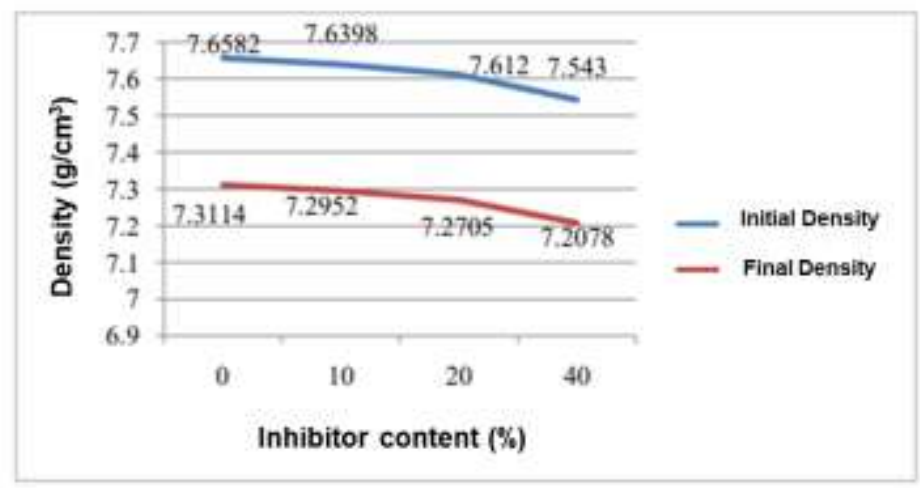

Figure 2. Graph of the relationship between iron metal density and ketapang leaf extract composition with soaking time for 6 days

Based on Figure 1 and Figure 2, at the time of immersion for 3 days, the minimum density value was obtained in ferrous metal with the addition of an inhibitor of $40 \%$, which is $7.2002 \mathrm{~g} / \mathrm{cm}^{3}$, and the maximum density value occurs without the addition of an inhibitor, which is 7.3130 
$\mathrm{g} / \mathrm{cm}^{3}$. Likewise, in the test with immersion for 6 days, the minimum density value occurred in ferrous metal soaked using corrosion media with the addition of $40 \%$ ketapang leaf extract inhibitor with a large density of $7.2078 \mathrm{~g} / \mathrm{cm}^{3}$. And the maximum density value occurs without the addition of an inhibitor, which is $7.3114 \mathrm{~g} / \mathrm{cm}^{3}$.

\subsection{Chemical Properties (Corrosion Rate) of ketapang leaf extract as inhibitor}

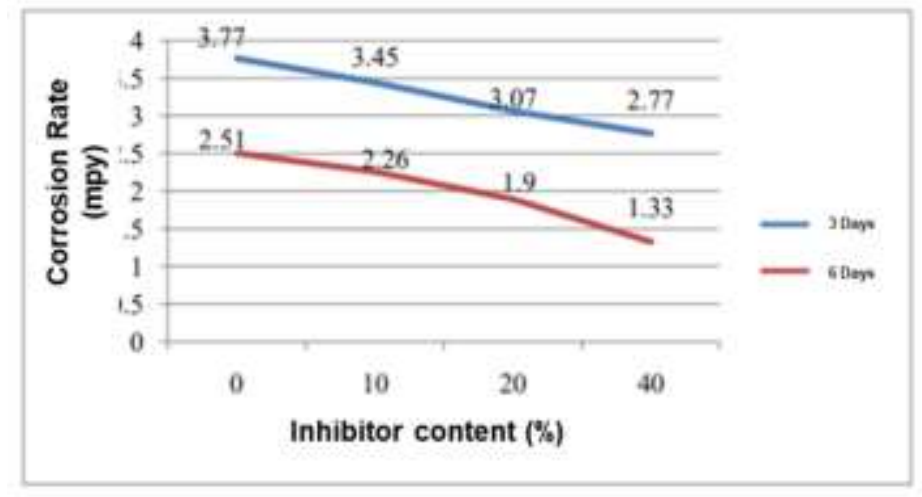

Figure 3. Graph of ferrous metal corrosion rate test results with an inhibitor composition of 0 ,

$10 \%, 20 \%$ and $40 \%$ in a seawater solution for 3 and 6 days

Based on Figure 3, the value of the corrosion rate will decrease with the increase in the inhibitor composition of the ketapang leaf extract with a soaking time for 3 days and 6 days. For the immersion time for 3 days, the maximum corrosion rate value obtained for ferrous metal without the addition of an inhibitor was $3.77 \mathrm{mpy}$, and will continue to decrease with increasing the amount of inhibitor in the corrosion medium. The minimum corrosion rate value was obtained for ferrous metal with the addition of $40 \%$ inhibitor, which was 2.77 mpy. Whereas for the immersion time for 6 days, the maximum corrosion rate value obtained for ferrous metal without the addition of an inhibitor was $2.51 \mathrm{mpy}$. The corrosion rate will continue to decrease with the addition of inhibitor concentration. So that the minimum corrosion rate value is obtained for ferrous metal with the addition of $40 \%$ inhibitor, which is $1.33 \mathrm{mpy}$. The percentage decrease in metal corrosion rate also continued to decrease with the addition of inhibitor concentration and immersion time.

At a concentration of $10 \%$ inhibitor immersed for 3 days, the percentage of corrosion rate was $8.49 \%$, at a concentration of $20 \%$ for 3 days, the percentage increased to $11.01 \%$, and when immersed at a concentration of $40 \%$ for 3 days, the percentage increased to $9.77 \%$. Likewise for metals immersed in corrosion media with an inhibitor concentration of $10 \%$ for 6 days, the percentage of the corrosion rate was $9.96 \%$, at a concentration of $20 \%$ for 6 days, the percentage increased to 15.93 when soaked at a concentration of $40 \%$ for 6 days, the percentage rose to $30 \%$. 


\subsection{Inhibitor Efficiency}

In Figure 4, it is found that the efficiency of the corrosion rate has increased in line with the addition of the inhibitor and also the length of soaking time in the sample immersed in 3 days which is $10 \%$ inhibited is $8.49 \%$, the $20 \%$ inhibited sample is $18.57 \%$, while in the inhibited sample $40 \%$ of $26.53 \%$. The samples immersed in 6 days the $10 \%$ inhibited were $9.96 \%$, the $20 \%$ inhibited samples were $24.30 \%$, while the $40 \%$ inhibited samples were $47.01 \%$ This shows that the more inhibitor concentrations are added to the corrosion medium, the higher the rate efficiency. Corrosion will be even greater. That is, the relationship between the corrosion rate and the test time is influenced by the concentration of inhibitor added to the corrosion medium.

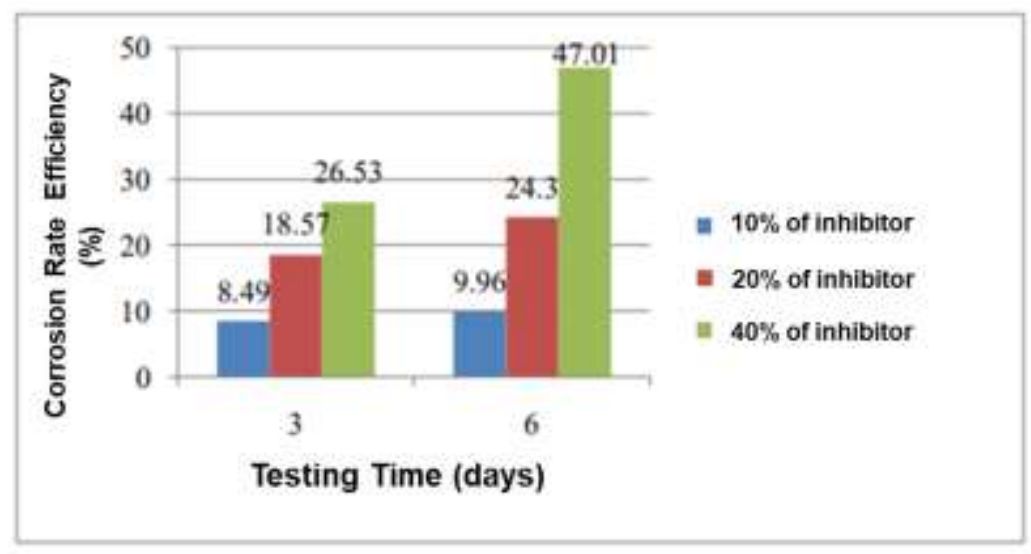

Figure 4. Corrosion rate efficiency diagram against immersion time

\subsection{Mechanical Properties (Hardness)}

Based on Figure 5, it can be seen that the metal hardness value will continue to increase with the addition of the inhibitor concentration. In the immersion process for 3 days, it was seen that the greatest hardness value when the corrosion medium was added was $40 \%$ inhibitor concentration with a hardness value of $162.164 \mathrm{~kg} / \mathrm{mm}^{2}$. The percentage increase in the hardness value when the metal is immersed for 3 days in media that is not inhibited against the metal soaked with $10 \%$ inhibitor is $4.64 \%$, meanwhile, the percentage increase in the hardness value of metal with $10 \%$ inhibitor against $20 \%$ inhibitor is $0.91 \%$, and the percentage increase in the value of hardness in metals with $20 \%$ inhibitor to $40 \%$ inhibitor is $1.6 \%$.

Likewise, the hardness value of the metal when immersed for 6 days, the hardness value tends to increase with the addition of an inhibitor to the corrosion medium. It can be seen that the greatest hardness value when the inhibitor concentration is added is $40 \%$ with a hardness value of $165.063 \mathrm{~kg} / \mathrm{mm}^{2}$. The percentage increase in the hardness value when the metal is immersed for 6 days in media that is not inhibited against the metal soaked with $10 \%$ inhibitor is $6.71 \%$, meanwhile, the percentage increase in the hardness value of metal with $10 \%$ inhibitor against $20 \%$ inhibitor is $1.02 \%$, and the percentage increase in the value of hardness in metals with $20 \%$ inhibitor to $40 \%$ inhibitor is $5.16 \%$. 


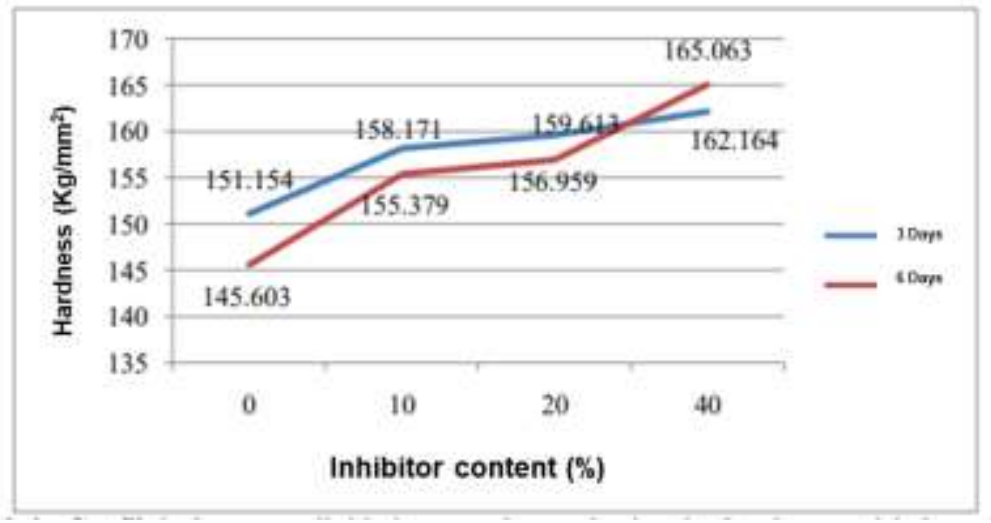

Figure 5. Graph of the relationship between the iron metal hardness value of the ketapang leaf extract composition with immersion time for 3 days and 6 days

\section{Conclusion}

With the greater the addition of an inhibitor to the corrosion media, the corrosion rate will decrease both by testing for 3 days or 6 days. The largest percentage of reduction in the corrosion rate in the corrosion media with the addition of inhibitor $40 \%$ for 3 days and 6 days is 9.77\% and 30\%. From this research, the longer the immersion time, the corrosion rate will continue to decrease along with the increase in inhibitor concentration and the length of soaking time. The density value decreased with the addition of inhibitor concentration. This happened because of the process of decreasing metal mass when immersed in the corrosion media, and the maximum density values occurred at immersion time of 3 and 6 days with uninhibited corrosion media, namely $7.3130 \mathrm{~g} / \mathrm{cm}^{3}$ and $7.3114 \mathrm{~g} / \mathrm{cm}^{3}$. And the minimum density values occurred at the immersion time of 3 and 6 days with $40 \%$ inhibited corrosion media, namely $7.2002 \mathrm{~g} / \mathrm{cm}^{3}$ and $7.2078 \mathrm{~g} / \mathrm{cm}^{3}$. The value of hardness will increase along with the increasing concentration of inhibitor ketapang leaf extract on the corrosion medium. In the immersion process for 3 and 6 days, the greatest hardness value when the corrosion medium was added was $40 \%$ inhibitor concentration with hardness values of $162.164 \mathrm{~kg} / \mathrm{mm}^{2}$ and $165.063 \mathrm{~kg} / \mathrm{mm}^{2}$. The greatest inhibitor efficiency value occurred in the corrosion media which added $40 \%$ ketapang leaf extract with soaking time for 6 days, which was $47.01 \%$. Meanwhile, the smallest efficiency value occurred in the corrosion medium which added $10 \%$ ketapang leaf extract with a soaking time for 3 days, which was $8.49 \%$.

\section{REFERENCES}

[1] C. Bolm, "A New Iron Age," Nature chemistry, vol. 1, pp. 420, 2009.

[2] P. M. Clarkson and E. M. Haymes, "Exercise and Mineral Status of Athletes: Calcium, Magnesium, Phosphorus, and Iron," Medicine and Science in Sports and Exercise, vol. 27, no. 6, pp. 831-843, 1995.

[3] I. A. Schonmetz and K. Gruber, Pengetahuan Bahan dalam Pengerjaan Logam (BK), Bandung: Penerbit Angkasa, 2013. 
[4] Kr. Tretheway and J. Chamberlain. Korosi untuk Mahasiswa dan Rekayasawan, Jakarta: PT.Gramedia Pustaka Utama, 1991.

[5] M. Bethencourt, F. J. Botana, J. J. Calvino, M. Marcos and M. A. RodrÍguez-Chacón, "Lanthanide Compounds as Environmentally-Friendly Corrosion Inhibitors of Aluminium Alloys: A Review," Corrosion Science, vol. 40, no. 11, pp. 1803-1819, 1998.

[6] V. Saraswathy and H-W. Song, "Improving the Durability of Concrete by Using Inhibitors," Building and Environment, vol. 42, no. 1, pp. 464-472, 2007.

[7] P. A. Schweitzer, Corrosion of Linings \& Coatings: Cathodic and Inhibitor Protection and Corrosion Monitoring, USA: CRC Press Taylor \& Francis Group, 2006.

[8] V. S. Sastri, Green Corrosion Inhibitors: Theory and Practice, New Jersey: John Wiley \& Sons, Inc, 2011.

[9] R. S. Irianty and Khairat, "Ekstrak Daun Pepaya sebagai Inhibitor Korosi pada Baja AISI 4140 dalam Medium Air Laut," Jurnal Teknobiologi, vol. IV, no. 2, pp. 77-82, 2013.

[10] J. M. Gaidis, "Chemistry of Corrosion Inhibitors," Cement and Concrete Composites, vol. 26, no. 3, pp. 181-189, 2004.

[11] Nursyamsi, M. Zakir and S. Dali, "Utilization of Ketapang Leaf Etil Asetic Fraction (Terminalia catappa) as a Bioreductor in Synthesis of Silver Nanoparticles and Analysis of The Antibacterial Properties," Jurnal Akta Kimia Indonesia (Indonesia Chimica Acta), vol. 10, no. 2, pp. 56-67, 2017.

[12] E. Triana and N. Nurhidayat, "The Assessment of Ketapang (Terminalia catappa L.) Leaves Water Extract as Natural Cleaning Agent Using Clean in Place (CIP) Method," in Prosiding Seminar Nasional II Tahun 2016, Kerjasama Prodi Pendidikan Biologi FKIP dengan Pusat Studi Lingkungan dan Kependudukan (PSLK) Universitas Muhammadiyah Malang, pp. 143-155, 2016. 